\title{
СУЧАСНІ ПІДХОДИ ДО АНТЕНАТАЛЬНОЇ ТА ПОСТНАТАЛЬНОЇ ДІАГНОСТИКИ ГЕМОЛІТИЧНОЇ ХВОРОБИ (ОГЛЯД ЛІТЕРАТУРИ)
}

Вищий державний навчальний заклад України «Буковинський державний медичний університет», м. Чернівці

Резюме. У статті наведені дані літератури щодо антенатальної та постнатальної діагностики гемолітичної хвороби, спричиненої ізосенсибілізацією організму жінки антигенами системи Резус.
Ключові слова: гемолітична хвороба, ізоімунізація, резус-конфлікт, діагностика.
Гемолітична хвороба плода і новонародженого, зумовлена анти-D антитілами, досі зумовлює найвищий відсоток захворюваності й смертності плодів і новонароджених серед причин, пов'язаних з імунним гемолізом [25]. У деяких D-позитивних новонароджених при прямому антиглобуліновому тесті можуть не спостерігатися ознаки деструкції еритроцитів або вони можуть бути дуже помірними і проявлятися тільки розвитком незначної гіпербілірубінемії у перші два дні життя і дещо швидшим, ніж зазвичай, падінням концентрації гемоглобіну в перші 10 діб. При значнішому ураженні жовтяниця й анемія можуть прогресувати дуже швидко i, якщо дитині своєчасно не буде проведена операція замінного переливання крові, можливий розвиток ядерної жовтяниці - найбільш небезпечного і прогностично несприятливого ускладнення гемолітичної хвороби новонароджених ГХН [32]. У плодів із вираженим гемолізом тяжка анемія й водянка розвиваються внутрішньоутробно, що призводить до загибелі плода. Сдино ефективним і сучасним засобом лікування цієї форми є переливання крові плоду [33]. У той же час, неадекватна терапія ГХН у внутрішньоутробному і ранньому неонатальному періодах може призвести до високої інвалідизації хворих [3], зумовленої ураженням ЦНС [35]. Серед дітей, які перенесли тяжку гіпербілірубінемію, значно вищий відсоток пацієнтів, які перебувають у лікарів-психіатрів, ніж у середньому в популяції [26]. У зв'язку з цим, гостро постає питання своєчасної діагностики гемолітичної хвороби, особливо ії початкових проявів в антенатальному періоді.

Нова ера в діагностиці та значні успіхи в лікування ГХП пов'язані 3 публікацією робіт A.W. Liley (1961). Для здійснення діагностики й оцінки ступеня тяжкості ГХП A.W. Liley впровадив амніоцентез і визначення оптичної щільності навколоплідних вод, для тяжких форм ГХП розробив метод внутрішньоматкового інтраабдомінального переливання крові плоду під рентгенологічним контролем [7]. Починаючи з 1961 р., аналіз оптичної щільності навколоплідної рідини, отриманої при амніоцентезі, був основним методом діагностики ступеня тяжкості ГХ. Проте незважаючи на те, що амніоцентез становить менший ризик для плода, ніж кордоцентез, він менш інформативний. Передусім, йдеться про високу (с) О.М. Юзько, Л.В. Дубик, 2016 218 частоту псевдопозитивних і псевдонегативних результатів, особливо в II триместрі вагітності, і про необхідність повторних 2-4-разових операцій амніоцентезу [2]. Водночас із розвитком нових технологій стало можливим з 1-2 мл навколоплідних вод визначити Rh-приналежність плода методом ПЛР, або подвійної ПЛР з флюоресцентною чи лазерною оцінкою результатів. При використанні праймерів це визначення може бути проведене на аксонах 10, 4, 5, 7. Точність генотипування за амніоцитами відповідає серотипуванню крові й становить 99,4 \%. Чутливість методу 99,5\%, специфічність - 98,8 \%. Антенатальну оцінку тяжкості захворювання найнадійніше проводити за результатом зразка крові плода, отриманому шляхом кордоцентезу. У цьому випадку 3'являється можливість визначити групу крові і $\mathrm{Rh}$-приналежність, DAT, рівень гемоглобіну, гематокриту, білірубіну, альбуміну [1]. Проте кордо- й амніоцентез, будучи інвазивними методами дослідження, можуть спровокувати трансплацентарний гемораж i, як наслідок цього, - зростання титру АТ [28]. Тому, незважаючи на наявність нових сучасних методів оцінки стану внутрішньоутробного плода, до теперішнього часу велике значення в антенатальній діагностиці ГХ мають неінвазивні методики, зокрема, визначення титру АТ у крові матері. Збільшення й високі значення титру Rh-антитіл у сироватці крові жінки частіше (але не обов'язково) дозволяють очікувати на тяжчий перебіг захворювання. Особливо виявляються на початку вагітності [36]. Проте, на думку окремих авторів, відмічена добра кореляція між часом появи АТ, їх титром і тяжкістю захворювання тільки при першій вагітності, за якої виявлена сенсибілізація. При повторних вагітностях із резус-імунізацією цієї кореляції немає. Часта зміна підйомів і спадів титру неповних антитіл, що відзначається в першій половині вагітності, є характерною ознакою виникнення імуноконфліктних реакцій між матір'ю і плодом [24]. Крім того, вважається, що чим вищий титр АТ у матері в процесі вагітності, тим інтенсивніший гемоліз еритроцитів у плода і новонародженого. Проте на практиці така закономірність проявляється далеко не завжди [29]. Це пояснюється тим, що титр АТ $є$ кількісною, а не функціональною (якісною) характеристикою АТ. Показником же функціональної активності АТ є авідність, яка 
Число антигенних сторін еритроцитів різних фенотипів

\begin{tabular}{|c|c|c|}
\hline Фенотип & Можливий генотип & Число антигенних сторін \\
\hline CcDee & $\mathrm{CDe} / \mathrm{cde}$ & $9900-14600$ \\
\hline $\mathrm{ccDee}$ & $\mathrm{cDe} / \mathrm{cde}$ & $12000-20000$ \\
\hline $\mathrm{ccDEe}$ & $\mathrm{cDE} / \mathrm{cde}$ & $14000-16600$ \\
\hline $\mathrm{CCDee}$ & $\mathrm{CDe} / \mathrm{CDe}$ & $14500-19300$ \\
\hline $\mathrm{CcDEe}$ & $\mathrm{CDe} / \mathrm{cDE}$ & $23000-31000$ \\
\hline $\mathrm{ccDEE}$ & $\mathrm{cDE} / \mathrm{cDE}$ & $15800-33300$ \\
\hline
\end{tabular}

й характеризує здатність АТ взаємодіяти з антигеном. Крім зв'язуючої здатності АТ на реакцію між антигеном і антитілом впливають $\mathrm{pH}$ середовища і температура, при якій проходить реакція. На величину титру АТ також впливають еритроцити, що можуть потрапляти до реагентів. Крім того, Rochna E. й Hughes J. N. (1965), використовуючи мічену 125I антиглобулінову сироватку, виявили, що число антигенних сторін на еритроцитах різних фенотипів різне. Кількісна характеристика антигенних сторін еритроцитів різних фенотипів представлена в таблиці.

3 цієї таблиці випливає, що еритроцити 3 великим числом антигенних сторін за інших рівних умов зв'язуватимуть більше число антитіл. Більше того, у D-сенсибілізованої вагітної титр $\mathrm{Rh}$-антитіл може підвищуватися i при Rhнегативному плоді [5]. Багато дослідників вважають, що титр АТ не може служити достовірним показником тяжкості захворювання плода, оскільки відомо, що при низькому титрі АТ можуть народжуватися мертві або тяжко хворі діти і навпаки, при високому титрі - здорові [21]. Є поняття критичного рівня АТ, під яким розуміють рівень АТ, коли не було зареєстровано загибелі плода або новонародженого від ГХ. Критичний рівень АТ коливається від 1:8- 1:16 до 1:32 [2]. Проте судити про тяжкість ураження плода при Rh-конфлікті на підставі титру АТ можна 3 певною упевненістю лише під час вагітності, при якій антитіла з'явилися уперше.

При наступних вагітностях багаторазова резус-антигенна дія призводить до рефлекторного подразнення імунокомпетентних систем організму жінки. Як стимулятор продукції АТ може виступати вже не специфічний $\mathrm{AГ}$, а сам плід, у тому числі й той, що не має цього специфічного антигену [7]. 3 другого боку, невідповідність між тяжкістю ГХ і титром АТ можна пояснити неоднаковою здатністю плаценти здійснювати захисну функцію. Разом з цим у жінок з явищами резус-сенсибілізації частіше виявляється підвищена чутливість до інших антигенів крові людини, таких, як лейкоцитарні і тромбоцитарні антигени. Встановлено, що поєднана сенсибілізація до еритроцитарних і лейкоцитарних антигенів несприятливо впливає на плід більшою мірою, ніж сенсибілізація тільки до резус-фактора [7]. Таким чином, величина титру анти-D антитіл має лише відносне значення як для прогнозу висліду вагіт- ності, так і наявність резус-конфлікту між матіp'ю і плодом. Виявлення в крові вагітної АТ дозволяє зробити висновок про вірогідність захворювання плода.

Останнім часом, у зв'язку з початком застосування імунопрофілактики анти-D імуноглобуліном велику актуальність набула проблема ГХН, зумовлена анти-с антитілами $[13,16]$. Хоча в міру імуногенності він поступається D-антигену, 20 \% новонароджених з с-позитивним типом крові, матері яких мали анти-с антитіла, потребували замінного переливання крові. Інші антитіла Rhспецифічності (анти-С, анти-Е, анти-е) доволі рідко виявляються при діагностиці ГХН і призводять до розвитку хвороби середнього ступеня тяжкості [15]. У той же час, наводять одиничні описи випадків тяжкої форми ГХН і смерті плодів, зумовлені антитілами цього роду. Тому для своєчасного виявлення ГХН, зумовленої „рідкісними” антитілами, потрібний скринінг усіх вагітних на наявність спектра і регулярних AT, у тому числі й „мінорних”, а до призначення будь-якої терапії необхідно фенотипувати еритроцити плода.

За даними ряду авторів $[4,9,16]$, для прогнозу ГХП певне значення має генотип крові батька дитини відносно антигенів системи Rh. Відомо, що вірогідність виникнення ГХ у плода в 4 рази більша при гомозиготному типі крові батька. У той же час, за даними [21] у 16 батьків, діти яких померли від ГХ, у п'яти була кров гетерозиготного типу . Слід зазначити, що визначення генотипу батька украй важливе у світлі розвитку сучасних медичних технологій, зокрема в програмі антенатальної профілактики резус-сенсибілізації в неімунізованих жінок Ig анти-D.

Таким чином, комплексний імунологічний аналіз крові батьків є найважливішою складовою частиною обстеження при імуноконфліктній вагітності. У той же час, результати імунологічних досліджень не дозволяють в усіх випадках достовірно встановлювати діагноз захворювання плода і прогнозувати вислід вагітності.

Доповненням для виявлення ГХ є ультразвукове дослідження плода. Виявлення за допомогою УЗД збільшення розмірів живота, печінки, селезінки плода, а також товщина плаценти, багатоводдя, асцит, встановлення подвійного контура голівки плода можуть бути пов'язані з розвитком ГХ [2]. Однією з найбільш ранніх ознак ГХП є 
збільшення розмірів плаценти [12]. Проте на практиці, потовщення плаценти виявляється у $1 / 3$ усіх вагітних, а при тяжкій формі ГХ - у 2/3 пацієнток. У зв'язку з цим, запропонована методика оцінки об'єму плаценти залежно від її локалізації в матці та форми плодової частини. Встановлено, що при ГХП об'єм плаценти збільшений при усіх ступенях тяжкості порівняно з неускладненою вагітністю, але найбільший приріст об'єму плаценти спостерігається при тяжкій формі ГХ. Зокрема, при легкій формі ГХП об'єм плаценти збільшується в середньому на $69,03 \pm 6,01 \mathrm{~cm}^{3}$ у $75 \%$ вагітних, при середньому ступені тяжкості - на $221,12 \pm 19,26$ см $^{3}$ у 84 \% обстежених і при тяжкій формі захворювання - на 421,05 $\pm 39,59 \mathrm{~cm}^{3}$ у $95 \%$ вагітних [7]. Проте у деяких вагітних з тяжкою формою ГХП об'єм плаценти може бути знижений, якщо імунний конфлікт розвивається на тлі плацентарної недостатності, що є несприятливою прогностичною ознакою [8].

Другою, за частотою виявлення, ультразвуковою ознакою вважається збільшення розмірів печінки. Проте гепатомегалія найбільш характерна для набрякової форми ГХ, у діагностиці легкого або середнього ступеня тяжкості ГХ ця ознака ультразвукового сканування малоінформативна, а візуалізація характерних для ГХП змін печінки затруднена. У зв'язку з цим запропонована оцінка непрямих ознак, на підставі якої можна судити про ступінь гепатомегалії: зміна форми і зміщення шлунка плода, визначення об'єму печінки плода [14]. Ще однією відмінною особливістю ГХП, що визначається за допомогою УЗД, є оцінка дихальних рухів плода, що дозволяє виявити початкові стадії ГХП [23]. При легкій формі захворювання частота дихальних рухів знижена в 2 рази порівняно 3 нормативними значеннями, а індекс дихальних рухів - в 1,98 раза порівняно 3 нормативними показниками. При тяжкій формі ГХП частота й індекс дихальних рухів знижені в 3 і 3,5 раза відповідно. При набряковій формі захворювання дихальних рухів плода практично немає. Таким чином, методи ультразвукової діагностики високоінформативні тільки для тяжких форм ГХ, в основному для набрякової форми захворювання. За відсутності тяжкої форми жоден із параметрів фето- і плацентометрії не $\epsilon$ достовірним критерієм оцінки ступеня тяжкості ГХП [34]. В останні десятиліття повсюдного поширення в діагностиці ГХП набуло доплерометричне дослідження [22], що дозволяє виявити зміну систоло-діастолічного відношення, а також індексу резистентності при наростанні ступеня тяжкості ГХП. Ці зміни пов'язані з підвищенням судинного опору плодової частини плаценти, що може бути зумовлено змінами в плаценті та/або порушеннями судинозвужувальних і судинорозширювальних систем плодово-плацентарного комплексу. Однак найбільшу діагностичну цінність має доплерометрична оцінка кровоплину в середній мозковій артерії плода, яка корелює 3 тяжкістю анемії при ГХП [33]. Швидкість потоку систоли крові в середній мозковій артерії плода $є$ вирішальною в тактиці переходу від неінвазивних методів оцінки ступеня тяжкості ГХП до інвазивних [30]. Так, швидкість кровоплину в середній мозковій артерії при анемії у плода вища, ніж у плода того ж терміну гестації без анемії, а ступінь зміни швидкості кровоплину обернено корелює з рівнем гематокриту. Швидкість кровоплину 1,69 МоМ вказує на тяжку анемію плода, при показниках 1,32 МоМ у плода визначається анемія середнього ступеня. Чутливість методу $100 \%$, а несправжньо-позитивні результати були отримані тільки в $12 \%$ випадків [27].

У той же час, деякі автори вказували на неінформативність доплерометричних даних у діагностиці ступеня тяжкості ГХ [25].

У вітчизняній медицині практично не застосовуються такі методики, як визначення підкласів IgG та клітинний біоаналіз. При виявленні тільки IgG3 анти-D тяжкість ГХН була менша, ніж коли були виявлені IgG1 або IgG1 + IgG3 [18]. Серологічні тести не відображають функціональної активності АТ, для цього потрібний клітинний біоаналіз.

Антитілозалежна клітинна цитотоксичність, хемілюмінесцентний тест є найпривабливішими серед неінвазивних методів оцінки ступеня активності АТ [31]. Вони складніші у виконанні, ніж визначення концентрації АТ, але при їх застосуванні знижується необхідність проведення кордой амніоцентезів [20]. Уперше метод визначення цитотоксичності AT (antibodycell-mediatedcytotoxicityassay - ACMCA) був запропонований у 1984 р. і з того часу рутинно використовується в Нідерландах. Метод заснований на оцінці ступеня цитотоксичного лізису моноцитами резуспозитивних еритроцитів донора, що мітяться радіоактивним Cr51 i змішаних 3 нерозведеною сироваткою матері. Ступінь цитотоксичного лізису визначається шляхом підрахунку Cr51 активності в супернатанті й виражається як відсоток ступеня лізису поліклональними анти-D антитілами за калібрувальною кривою. При значенні $\mathrm{ACMCA}<10 \%$ - плід здоровий і ризику ГХ немає. При рівні цього показника від 30 до $50 \%$ розробляти інвазивні тести для оцінки стану плода немає необхідності. При показниках АCMCA $>50 \%$ необхідно використовувати інвазивні методи діагностики ГХ [19]. Багато дослідників намагалися знайти інші показники для визначення алоімунізації вагітної і тяжкості ГХН, але ці показники мають допоміжне значення і тільки доповнюють імунологічні обстеження. Деякі дослідження, присвячені вивченню біомікроскопії судин кон'юнктиви ока [19], визначенню рівня фетального гемоглобіну [11], змінам ренінальдостеронової системи плодово-плацентарного комплексу [4], комп'ютерній кардіотокографії [6]; стану мембран еритроцитів у плодів [10]; функціональній активності нейтрофільних гранулоцитів [9] та їх значенню в діагностиці гемолітичної хвороби плода. Окремі дослідники визна- 
чали речовини, наявні в амніотичних водах, метаболіти оксиду азоту, циклічний гуанозин 3',5'монофосфат і диметиларгінін [26], $\alpha$ фетопротеїн, загальний білок і рибонуклеазу [25], прогестерон і плацентарний лактоген [22], концентрацію мікроелементів [17].

Перспективний для антенатального визначення групи крові плода метод використання плодових еритроцитів, наявних у периферичній крові матері як джерело ДНК [2]. Метод заснований на принципі реплікаційного множення числа копій невеликого фрагмента ДНК (генетичних текстів). Для створення ПЛР-системи потрібний невеликий фрагмент ДНК, суворо специфічний для цього антигену, за допомогою ампліфікації його розмножують, а потім електрофорезом в агаразному гелі ідентифікують [21]. Запровадження цієї технології дозволяє з точністю до 96 \% визначити Rh-приналежність ембріона по одній клітині [8]. Очевидно, що в найближчому майбутньому вдосконалення методів виділення клітин крові плода в периферичній крові матері поступово витіснить із клінічної практики інвазивні втручання під час вагітності для визначення $\mathrm{Rh}$-генотипу плоду. Таким чином, в антенатальній діагностиці гемолітичної хвороби на перший план виступають методи імуногематологічного обстеження.

Постнатальна оцінка тяжкості ГХН не становить особливих складнощів і проводиться за рівнем гемоглобіну і білірубіну в сироватці пуповинної крові, наявності і вираженості набрякового синдрому, почасовим приростом рівня білірубіну, ознаками білірубінової ,інтоксикації”. Анемія може супроводжуватися нормобластозом, ретикулоцитозом. Прямий антиглобуліновий тест не $\epsilon$ показником тяжкості ГХН [3]. Для гемолітичної хвороби за системою Резус характерне виникнення пізніх гіпорегенераторних анемій у віці $(43 \pm 15)$ діб, незалежно від лікування у внутрішньоутробному і ранньому неонатальному періодах [10]. Таким чином, діагностика ГХ становить певні труднощі особливо на етапі внутрішньоутробного розвитку плода. Існуючі сучасні неінвазивні методи діагностики цього захворювання належать до категорії дорогих і залишаються, як i раніше, недоступними для більшості лікувальних установ. У той же час, в Україні немає систематизованих діагностичних критеріїв ГХ плода, що розвивається, які були б доступні кожному лікареві-перинатологу, не вимагали б проведення додаткових діагностичних досліджень і не збільшували вартість скринінгового обстеження вагітних 3 Rh-негативним типом крові. Існуючі критеpiï діагностики доволі суперечливі та не дають практичному лікареві чіткого уявлення про тактику ведення Rh-сенсибілізованої вагітної.

\section{Література}

1. Айламазян Э.К. Антенатальная диагностика и коррекция нарушений развития плода / Э.К. Айламазян // Рос. вестн. перинатол. и педиатрии. - 1999. - № 3. C. 6-11.
2. Айламазян Э.К. Интенсивная терапия при ведении Rhизоиммунизированной беременности / Э.К. Айламазян // Ж. акуш. и жен. болезней. - T. LII. - Выпуск 1/2003. - C. 56-59.

3. Актуальные вопросы акушерства: Руководство для врачей акушеров- гинекологов, интернов и студентов мед. университетов / Под ред. Коханевич Е.В. - К.: ТМК, 2001. $-152 \mathrm{c}$.

4. Белкина Е.В. Система резус: у кого и как определять резус-принадлежность / Е.В. Белкина, Н.И. Оловникова, И.Л. Чертков // Гематол. и трансфузиол. - 2003. № 9. - C. 46-48.

5. Волкова Л.С. Иммунобиологические взаимоотношения плода и материнського организма (клиникоэкспериментальные исследования): автореф. дисс. на соискание уч. ст. д-ра мед. наук / Л.С. Волкова. - М., 1967. $-20 \mathrm{c}$.

6. Воскресенский С.Л. Оценка состояния плода. Кардиотокография. Допплерометрия. Биофизический профиль: учебное пособие / С.Л. Воскресенский. - Мн.: Книжный дом, 2004. - 304 с.

7. Геворкян И.А. Информативность клинических и иммунологических маркеров гемолитической болезни плода и новорожденного: автореф. дис. на соискание уч. ст. канд. мед. наук. - 14.00 .09 - педиатрия, 14.00 .01 - акушерство и гинекология / И.А. Геворкян. - Новосибирск, 2005. - 24 с.

8. Жук С.Ш. Акушерські аспекти резус-конфліктної вагітності: діагностика, лікування, шляхи профілактики / С.Ш. Жук, В.I. Ошовський 2010 // Здоровье женщины. -2010 . - № 7. - С. 88-91.

9. Иммунология репродукции: пособие для врачей, ординаторов и научных работников / В.А. Алешкин, А.Н. Ложкина, Э.Д. Загородняя. - Чита, 2004. - 79 с.

10. Ізоімунізація по резус-фактору. Сучасний погляд на проблему / В. Квашенко, Б. Іотенко, К. Чайка // Мед.соц. пробл. сім'ї. - 2011. - Т. 16, № 3. - С. 97-102.

11. Комплексная пренатальная диагностика и лечение гемолитической болезни плода: возможности и перспективы / А.В. Макогон, М.А. Дегтярев, И.В. Андрюшина [и др.] // Рос. вестн. перинатол. и педиатрии. 2002. - T. 47, № 6. - С. 11-13.

12. Макогон А.В. Пиковая систолическая скорость кровотока в средней мозговой артерии как предиктор анемии плода. История развития и современное состояние диагностического метода / А.В. Макогон, И.В. Андрюшина // Ультразвук. и функционал. диагностика. - 2012. - № 1. - С. 83-94.

13. Минеева Н.В. Редкий случай анемии, обусловленной гемолитической болезнью новорожденного по сантигену эритроцитов, осложненный наличием аутоиммунной гемолитической анемии у матери / Н.В. Минеева, И.А. Пашкова, Г.В. Козина // Гематол. и трансфузиол. - 2003. - Т. 48, № 6. - С. 43-44.

14. Минеева Н.В. Группы крови человека. Основы иммуногематологии / Н.В. Минеева. - СПб., 2004. - 188 с.

15. Мороков В.А. Гемолитическая болезнь новорожденного, обусловленная материнскими антителами антиrh" (Е) / В.А. Мороков, И.В. Рау, М.Е. Мороцкая // Рос. вестн. перинатол. и педиатрии. - 1999. - № 4. C. $56-58$.

16. Мороков В.А. Значение «минорных» эритроцитарных антигенов при формировании кадров доноров, дающих кровь для переливання больным / В.А. Мороков // Гематол. и трансфузиол. - 2002. - Т. 37, № 11-12. - С. 46-48.

17. Найновіші досягнення в акушерстві та гінекології / Гол. ред. Грещишен М. - Львів: Бафало, 2000. - 516 с.

18. Оловникова Н.И. Антигены эритроцитов человека / Н.И. Оловникова, Т.Л. Николаева // Гематол. и трансфузиол. - 2001. - № 5. - С. 37-45. 
19. Оловникова Н.И. Д-антиген системы резус / Н.И. Оловникова, Е.И. Дерюгина // Гематол. и трансфузиол. - 2001. - № 12. - С. 22-25.

20. Пашкова И.А. Активация антителогенеза при резусгомоспецифической беременности / И.А. Пашкова, Г.В. Козина // Гематол. и трансфузиол. -2000 . - № 5 C. $45-46$.

21. Сидельникова В.М. Гемолитическая болезнь плода и новорожденного / В.М. Сидельникова, А.Г. Антонов. - М.: Триада-Х, 2004. - № 10. - С. 129.

22. Современные методики диагностики и лечения гемолитической болезни плода / А.Г. Коноплянников, В.Б. Евтеев, М.В. Лукашина [и др.] // Акуш. и гинекол. - 1999. - № 6. - С. 22-26.

23. Эффективность выявления изоиммунных антител в разных методах исследования у беременной с подозрением на резус-конфликт / Ю. Зайвый, Е. Алексеева, В. Серая [и др.] // Укр. ж. екстремал. мед. ім. Г.О. Можаєва. - 2010. - Т. 11, № 2. - С. 38-41.

24. Cherif-Zahar B. Localization of human Rh-blood group genestructur eto chromosom eregion Ip34.3-Ip36.1 by insity gibridization / B. Cherif-Zahar // Hum. Genetic. 2001. - № 86. - P. 348-400.

25. Consequences for fetus and neonate of maternal red cell floimmunisation / H. Howard, V. Martlew, J. McFadyen [et al.] // Arch. Dis. Child. Fetal. Neonatal. Ed. - 1998. № 78 (1). - P. 62-66.

26. Dalman C. Neonatal hyperbilirubinaemia - a vulnerability factor for ment all disorder? / C. Dalman, J. Cullberg // Acta. Psychiatr. Scand. - 1999. - № 100 (6). - P. 469-471.

27. Detti L. Doppler ultraso und velocimetry for timing these condun trauterine trausfision in fetuses with anemiffromred cell allo immunization / L. Detti // Am. J. Obstet. Gynecol. - 2011. - № 185. - P. 5.

28. Feto-maternal immunization and fetal hemolytic disease: invasive diagnostic sand therapy in the Warsaw center of serological collision in years 1992-1999 / M. Wielgos, T. Rokicki, A. Zajac Wiczynka [et al.] // Ginekol. Pol. 2000. - № 71 (6). - P. 524-531.

29. Gorman J. Anepidemiological and historical review of Rh-hemolytic diasease implication for management and prevention / J. Gorman, W. Pollack, V. Freda // Transfusion. - 1997. - Vol. 7, № 5. - P. 374-375.

30. Mari G. Middle cerebralartery peak systolic velocity for the diagnosis of fetalanemia: the untoldstory / G. Mari // Ultrasound Obstet. Gynecol. - 2005. - Vol. 25. - № 4. P. 323-330.

31. Mollison P.L. Blood transfusionin clinical medicine / P.L. Mollison, C.P. Engelfriet, M. Contreras. - Oxford London: Black Scientific Publication, 11 edition, 2007. -1033 p.

32. Murray N.A. Roberts I.A.G. Haemolytic disease of the newborn / N.A. Murray, I.A.G. Roberts // Arch Dis Child Fetal Neonat Ed. - 2007. - Vol. 92. - P. 83-88.

33. Oepkes D. Clinical Value of anantibody-dependentcellmediated cytotoxicityas say in the management of $\mathrm{RhDal}-$ lo immunization / D. Oepkes // Am. Obstet. Gynecol. 2001. - № 184. - P. 5.

34. Nicolaides K.H. Failure of ultrasonographic parameters to predict the severity of fet al anemisin rhesusiso immunisation / K.H. Nicolaides // Am. Obstet. Gynecol. - 2008. № 158. - P. 920-926.

35. RhD status of a fetusatrisk for haemolytic disease with a discrepant maternal DNA-based $\mathrm{RhD}$ genotype / G.A. Denomme, H. Akoury, M. Sermer [et al.] // Prenat. Diagn. - 1999. - № 19 (5). - P. 424-427.

36. Woodrow J. Rh-immunisation by pregnancy: results of a survey and theirrelevanc eto prophylactic therapy / J. Woodrow, W. Donohoe // Brit. Med. J. - 1968. - № 2. P. 139.

\section{СОВРЕМЕННЫЕ ПОДХОДЫ К ДИАГНОСТИКЕ АНТЕНАТАЛЬНОЙ И ПОСТНАТАЛЬНОЙ ГЕМОЛЕТИЧЕСКОЙ БОЛЕЗНИ (ОБЗОР ЛИТЕРАТУРЫ)}

\section{О.М. Юзько, Л.В. Дубик}

Резюме. В статье представлены данные литературы об антенатальной и постнатальной диагностике гемолитической болезни, причиной которой является изосенсибилизация организма женщины антигенами системы Резус.

Ключевые слова: гемолитическая болезнь, изоиммунизация, резус-конфликт, диагностика.

\section{MODERN APPROACHES OF ANTENATAL AND POSTNATAL DIAGNOSTIC OF HAEMOLYTIC DISEASE (REVIEW OF THE REFERENCES )}

\section{O.M. Yuzko, L.V. Dubyk}

Abstract. The article presents literature data on antenatal and postnatal diagnostic of hemolytic disease caused by the female body immunization by Rhesusantigens.

Key words: hemolytic disease, immunization, Rh-conflict, diagnostic.

Higher State Educational Institution of Ukraine "Bukovinian State Medical University "(Chernivtsi)

Рецензент - проф. О.В. Кравченко

Buk. Med. Herald. - 2016. - Vol. 20, № 2 (78). - P. 218-222

Надійшла до редакції 04.04.2016 року

() О.М. Юзько, Л.В. Дубик, 2016 